\title{
NOTES
}

\section{MOTION PICTURES AND THE FIRST AMENDMENT}

UNDER a Constitution which tries to minimize arbitrary restraints on speech, state and municipal censorship of motion pictures occurs with almost no judicial control. ${ }^{1}$ Movies may be cut or banned by permanent censorship boards in advance of exhibition, ${ }^{2}$ removed from exhibition by police or

1. For discussions of movie censorship and its implications for freedom of expression see Chafee, Free Speech in the United States 540-548 (1941); Ernst, The First Freedour 181-244 (1946); Harley, World Wide Influence of Motion Pictures (1941); Inglis, FreEdom of THE Movies (1947). Legal aspects of the movie censorship problem are treated in Kupferman \& O'Brien, Motion Picture Censorship-The Memphis Blucs, 36 CoRneli L. Q. 273 (1951); Comments, 49 YALE L. J. 87 (1939), 39 Cor. L. REv. 1383 (1939).

In contrast with state and municipal movie censorship, federal activity in this field is quite limited. One federal statute forbids the interstate transportation of any "obscene, lewd, or lascivious, or any filthy ... motion picture film." 41 Stat. 1060 (1920), 18 U.S.C. 1462 (1946). But there have been no prosecutions under this statute for several years. Communication to Yale Law Journal from Mr. James M. McInerney, Assistant Attorney General, Dec. 15, 1950 in Yale Law Library. The Tariff Act forbids the importation of any film which is immoral or obscene or which advocates treason or subversion. 46 STAT. 688 (1930), 19 U. S. C. 1305 (1946). A recent order of customs officials excluded the film We Want $A$ Child from the United States because it contained a detailed scene of child delivery. 159 Publisher's WeErLy 254 (1951). There have been numerous unsuccessful attempts to pass federal censorship legislation. For early efforts see Inglis, supra, at 69-70; Comment, 49 Y YLE L. J. 87, 102 (1939). The most recent proposal was submitted by Senator Johnson after the public reaction to the BergmanRosselini affair. His Motion Picture Licersing Act would have required licensing of all actors, actresses, producers and directors. Licenses would be revocable upon conviction for a crime involving moral turpitude or upon admission by the licensee that he had engaged in immoral conduct. S.3237, 81st Cong., 2d Sess. (1950). Although this bill was not acted upon by the Senate, a resolution was adopted expressing the sense of the Senate that films directed or produced by totalitarian-minded persons should be banned from the United States, SEN. REs. 321, 81st Cong., 2d Sess. (1950).

2. Censor boards with the power to pass on all films in advance of exhibition exist in a number of states. See Kansas Gen. Stat. AnN. c. 51, c. 74, art. 22 (1949) ; MD. Ann. Code Gen. Laws art. 66A (Flack 1939) ; N. Y. Ev. LAw Art. 3, $\$ 120-132$ (Baldwin Dec. Supp. 1948); OHio Gen. Code Ann. \$154-47 (Page Supp. 1950) ; Pa. Stat. Ann. tit. 4, c. 2 (Purdon Supp. 1950) ; VA. Cone ANN. tit. 2-98 to 2-116 (1950). The Louisiana statute provides for a state censor board to approve all pictures in advance of exhibition, but the statute has not been actively administered. LA. REV. STAT. tit. 4, §§ 301-307 (1950), Kupferman \& O'Brien, supra note 1, at $276 \mathrm{n}$. 24. However, its existence forbids municipal censorship in the state. Joy Theatres v. Alexandria, (Municipal Court of Alexandria, July 15, 1946). In Massachusetts the Bureau of Lord's Day Entertainments views and licenses all films shown on Sundays. Mass. Ans. Laws c. 136, $\$ \S 2-4$ (1950). The quantity of film censored under these state statutes does not appear to be very large. The Director of the Motion Picture Division, N. Y. State Dept. of Education, Dr. Hugh 
licensing officials, ${ }^{3}$ or withdrawn under informal pressure from city officials. ${ }^{4}$ The argument for censorship is usually protection of community morality.

Flick, estimates that between five and fifteen films a year are not approved and about 900 deletions made in New York. The films not approved may be passed upon a second review after revision. In four months of 1950 , the Kansas State of Review disapproved only one picture, New Life, a reissue of Ecstacy. Elminations were required in five films. Typical of the deletions were the portions of dialogue eliminated from Caged: "You get a baby from a guy and 20 years later you finish him off," and "Oh, My God, Oh My God." Mimeographed Monthly Reports of Kansas State Board of Review, 1950.

Some cities provide for the prior approval of all films by a censor board or municipal official. In Chicago no film can be shown without a permit from the Police Commissioner. Rev. Chicago Code $\$ \$ 1952-1961$ (1931). Atlanta requires prior approval by the librarian of the Carnegie Library. Atranta CoDE $\$ \$ 5-305,58-107,58-108,66-504$ (1942). The tax collector issues permits in Houston. Houston City Code $\$ 1756$ (1942).

3. Under this type of censorship, action is taken against individual films found to be objectionable. The censoring agency does not view all films and grant permits, but bans pictures either on its own initiative or at the prompting of complaining citizens. Memphis provides that the censor board may call for a preview of any films it desires to see. MempHis Drgest v. $1, \S \S 1131-1139$ (1931). In Waterloo, Iowa, a three-member board of censors, a voluntary group chosen by the mayor, acts on complaint from outside sources and recommends action to the Mayor and City Council. Communication to YALE LAW Journar from Mayor Lawrence A. Touchae, Mayor of Waterloo, Iowa, December 5, 1950, in Yale Law Library. In Detroit all films must be submitted to the police department in advance. The department can reject an objectionable film, but does not issue approval permits. DetroIt Comp. Ord. c. 63, $\S \$ 20-22$ (1945).

4. Some municipalities which have no express censorship boards or ordinances use a less formal type of control through resort to licensing powers. Where theatre licenses are revocable at the pleasure of city officials it is possible to prevent the showing of a film by threatening to close the movie house. In Milwaukee the mayor has appointed a voluntary committee which recommends deletions or rejections. Although the committee has no formal standing its recommendations are accepted by the mayor and exhibitors must comply or lose their licenses. The statutory basis for this activity are the sections of the city code which provide that no theatre may be operated without a license and that the mayor may revoke the license at his discretion. MILwAUKEE CODE of ORDS., §§ 83.2, 83.7 (1941).

Another type of control, not strictly regarded as censorship, are ordinances providing fines and imprisonment for violation of laws against the showing of objectionable films. Under these laws all action is taken after exhibition. E.g., SALEN, ORE. ORd. \$9-110 (1939) provides for fines or imprisonment for showing a film "likely to provoke a breach of the peace or to invite a riot, or to arouse public indignation or resentment."

A variation from usual censorship procedures is reported in Communication to Y YLE Law Journal from Herbert E. Forsyth, Chief of Police, Denver, Colorado, Nov. 29, 1950 in the Yale Law Library. The city moves against most pictures only in a criminal prosecution after exhibition of a lewd or lascivious film. However, when a theatre plans to present "educational" films, such as those dealing with venereal disease and childbirth, the theatre manager always consults with the Captain of the Morals Bureau before showing the film. Such pictures are shown to segregated audiences, men on one day, women on another. There appears to be no explicit statutory authorization for this procedure. 
But in fact, broad statutory language ${ }^{5}$ and limited judicial review ${ }^{6}$ make possible the elimination of films on the basis of a highly subjective view of

5. Statutes usually provide that exhibition be forbidden for films that are "obscene, indecent, immoral, inhuman, sacrilegious or is of such a character that its exhibition would tend to corrupt morals or incite to crime." N. Y. Consol. Laws Art. 3, §122 (Baldwin Dec. Supp. 1948). Some statutes go beyond this and forbid films "inimical to the public safety, health, morals or welfare" or which seeks to denounce, deride or overthrow the present form of government. MeMrpis Digest vol. 1132 (1931). No statute regarding movie censorship has been found void for vagueness. A Pennsylvania court interpreted the statute which orders the censor board to disapprove films that are "sacrilegious, obscene, indecent or immoral" to set up a standard of propriety limiting the board's discretion. The court stated that without some standard of propriety read into the statute, it would be void for vagueness. In re "Spain in Flames," $36 \mathrm{~Pa}$. D. \& C. 285 (1937). In general, courts have not defined such words as "obscenity" in these statutes because of the limited nature of judicial review in movie censorship cases. For a description of the review process, see note 6 infra; for judicial definitions of obscenity applied to other media see note 31 infra.

6. The first step in the review process is usually administrative. The statute or ordinance setting up a censorship agency may direct that appeals be taken to a higher administrative tribunal [in Atlanta the librarian's decisions may be appealed to the Board of Trustees of the Carnegie Library, AtLaNTa CoDE $\$ 58-108$ (1942); in New York appeal is provided to the Board of Regents from a decision by the Motion Picture Division of the Education Department, N. Y. Ev. LAw Art. 3, \$124 (Baldwin Dec. Supp. 1948)] ; to an executive officer of the municipality [in Chicago, refusal of the Commissioner of Police to issue a permit may be appealed to the Mayor, whose action is final, REv. CEICAGo Code $\$ \S 1952,1954$ (1931)] ; or to the city council (Portland, Ore. Gen. Ord. $\$ 20-712(1950))$.

Judicial review after the exhibitor's administrative remedies have been exhausted may also be available. All state censorship statutes provide for appeal to the courts. In some municipalities, however, there is no provision for judicial review of the censor's decision. Menphis Drgest, $\S 1139$ (1931) makes the censor boards' findings of fact and conclusions of law final. Where the statute does not provide for court review, recourse to the courts may be had under mandamus, Schumann v. Pickert 277 Mich. 225, 269 N. W. 152 (1936) ; certiorari, Thayer Amusement Corp. v. Moulton, 63 R. I. 182, 7 A. $2 d$ 882 (1939) ; or injunction proceedings, United Artists Corp. v. Thompson, 339 Ill. 595, 171 N. E. 742 (1930).

No matter what appeal machinery is used, however, the reviewing agency does not usually see the film or pass on the censor's findings of fact. Only by proving abuse of discretion, which usually means censoring on some basis not provided for in the statute, can the exhibitor get a reversal of the censor's decision. See, e.g., Hygienic Productions v. Keenan, 1 N. J. Super. 461, 62 A. 2d 150 (Ch. Div. 1948) (license commissioner could not threaten to revoke license of a theatre presenting a birth control film when it was admitted that the film was not immoral and would be acceptable for non-commercial exhibition) ; City of Chicago v. Fox Film Corp., 251 Fed. 883 (7th Cir. 1918) (obscenity statute did not authorize license commissioner to ban film on the basis that a torture scene was too harrowing for children); Schumann v. Pickert, 277 Mich. 225, 269 N. W. 52 (1936) (police commissioner denied authority under an obscenity statute to ban a film because he felt it contained Soviet propaganda and was likely to instill class hatred).

In the great majority of cases, courts accept the censor's decision as practically final. See, e.g., Thayer Amusement Co. v. Moulton, 63 R. I. 182, 7 A. 2d 682 (1939) (refusal to review findings of fact or weigh evidence when licensing official denied approval to film because it was Communist propaganda and tended to provoke race hatred); In re 
morality ${ }^{7}$ or for reasons quite unrelated to moral standards. ${ }^{s}$ Now that im-

Goldwyn Distrib. Corp., 265 Pa. 335, 108 Atl. 816 (1919) (court will interfere only when abuse of discretion is attributed to "perversity of will, passion, prejudice, partiality or moral delinquency") ; Distinguished Films v. Stoddard, 271 App. Div. 715, 68 N. Y. S. 2d 737 (3rd Dep't 1947) ("some reviewing bodies would think this film offended, thus there is doubtless some evidence to sustain the finding").

7. The Chicago police commissioner cut a scene in Street with No Name in which a girl was slapped because he thought it an immoral episode. Life, Oct. 25, 1948, p. 60 . Pinky was banned in Memphis on the basis of obscenity and indecency. N. Y. Times, Oct. 19, 1950, p. 41, col. 2. Kiss Tomorrow Good-bye was banned in Ohio as an "extreme presentation of crime with explicit steps in its commission." N. Y. Times, Sept. 27, 1950, p. 36, col. 1. In a Communication to YaLE LAw JourNal from Mr. Hubert Drissen, Executive Secretary, Milwaukee Motion Picture Commission Dec. 14, 1950 in Yale Law Library are reported a number of deletions made upon recommendation of the Commission: Germany Year Zero ("offensive dialogue, scene of a boy about to poison someone and the fondling of a boy by his teacher"), I Was a Shoplifter ("teaching of a course in shoplifting") and Arctic Fury ("violence scene, that of a dog biting hand off man, repulsive"). It Happened in Europe was emasculated by the Ohio censors who deleted scenes of war orphans resorting to violence. The moral theme of the picture that such children could even then be saved by love and satisfaction of their basic needs for food and affection was thus lost upon the movie-goer in Ohio. Levy, The Case Against Film Censorship, Firars IN RevIEw, April, 1950, p. 40 (published by Nat1. Bd. of Review). Venereal disease and birth control films have frequently run into difficulty. Mom and Dad was banned recently in New York, Levy, supra at 40 , but an attempted ban by the Newark censor was overruled by the New Jersey courts because the censor admitted there was nothing immoral about the film. Hygienic Productions v. Keenan, 1 N. J. Super. 461, 62 A. 2d 150 (Ch. Div. 1948). Extrinsic considerations of personal lives of the stars were involved in bannings of Stromboli with Ingrid Bergman. For details of this controversy see N. Y. Times, Feb. 8, 1950, p. 33, col. 3; Feb. 12, 1950, Sec. II, p. 5, col. 1; p. 2, col. 4; Feb. 19, 1950, Sec. II, p. 1, col. 8. The Catholic Film Office in Rome said in refusing to condemn the film that the private lives of movie people should not be a factor in determining the suitability of a film. Because of this picture, Nashville, Tenn. created a censorship board and passed an ordinance providing for suppression of a picture where the producer, actor or actress has a reputation for laxity in morals. For discussion of considerations of private lives in the censorship process see Kupferman \& O'Brien, Motion Pictire Cerusorship-The Memphis Blues, 36 ConNarL L. Q. 273, 294-296 (1951). Memphis recently banned City Lights because the chief censor thought Charlie Chaplin a "London guttersnipe." Controversy was touched off last year by deletion of a scene in Bicycle Thief showing a boy urinating against a wall. N. Y. Times, April 2, 1950, Sec. II, p. 1, col. 7. A city court in Portland, Ore., said the City Council had acted arbitrarily and capriciously in eliminating the brothel scene from this picture. N. Y. Times, June 8, 1950 , p. 37 , col. 1 .

The problem in the present type of control is not only that films may be cut or banned for reasons which many in the community would not consider related to morality, but also that individual censors may look at the portrayal of some less than respectable activity and fail to relate that particular scene or piece of dialogue to the total purpose and effect of the film. A different situation prevails in criminal prosecutions for obscenity. See note 31 infra.

8. The Memphis censors banned The Southerner which dealt with poverty among tenant farmers because "it reflects on the south." Brewster's Millions was forbidden in Memphis because the radio and film character Rochester was deemed "too familiar." See Velio, You Can't See That Movie: Censorship in Action, Collier's, May 6, 1950, p. 11. 
portant political and social issues are receiving increasing attention in motion pictures, the demand has been raised anew that movies be granted the same freedoms accorded other organs of communication. ${ }^{9}$ The anomaly of the

Maryland restricted a Polish documentary film on the basis that it did not present a true picture of modern Poland and "appears to be Communist propaganda." Levy, Case Against Motion Picture Censorship, Frum IN Review, April 1950, p. 41 (published by Nat. Bd. of Review). I Was a Shoplifter was banned in Atlanta on the ground that it offered a course in shoplifting. N. Y. Times, April 30, 1950, sec. II, p. 5, col. 6. No Way Out was banned by the Chicago police department because "it could cause trouble." The principal objection to the film was that the conclusion showed no reconciliation between blacks and whites. The ban was lifted after a storm of protest and later deletion of a scene showing negroes arming for a gang fight with whites. N. Y. Times, Aug. 24, 1950, p. 31, col. 3; Aug. 31, 1950, p. 20, col. 8. This same film was forbidden for Sunday showing in Massachusetts. Ohio forbade its showing until the producer reedited the film. For other examples of censorship on political or social grounds see Kupferman \& O'Brien, Motion Picture Censorship-The Memphis Bhes, 36 CoRNerl L. Q. 273, 292-296 (1951) ; Comment, 49 Y ALE I. J. 87, 94-97 (1939) and cases cited note 6 supra.

9. The increased emphasis of motion pictures on areas of social controversy has touched off recent protests against film censorship. Two cases within the last year have been appealed to the Supreme Court. The first, United Artists Corp. v. Board of Censors of Memphis, 189 Tenn. 397, 225 S.W. 2d 550 (1949), cert. denied, 339 U. S. 853 (1950) resulted from the Memphis censor board's banning of Curley by the statement that "the South does not permit negroes in white schools nor recognize social equality between the races even in children." The Tennessee Supreme Court's decision upheld the ban but turned on the issue of the distributor's standing to sue rather than on the issue of censorship. The second, RD-DR Corp. and Film Classics, Inc. v. Smith 183 F. 2d 562 (5th Cir. 1950), cert. denied, 340 U. S. 853 (1950), contested the banning of Lost Boundaries in Atlanta. The banning was on the ground that showing the film would "adversely affect the peace, morals and good order" of that city. The Court of Appeals affirmed the censor's decision on the basis of Mutual Film Corporation v. Industrial Commission, 236 U. S. 230 (1915). A third case, appealing the banning of Pinky in Marshall, Texas, is now pending before the Texas Court of Criminal Appeals. See Kupferman \& O'Brien, supra note 1, at $286 \mathrm{n} .84$.

Movies are the one medium of mass communication not protected against arbitrary restraint. Although the Supreme Court has not specifically included radio and television within the scope of the First Amendment, the Communications Act of 1934 forbids the Federal Communications Commission from interfering with "the right of free speech by means of radio communication." The Act states that the Commission is not given the power to censor the content of radio programs. 48 STAT. 1064, 1091 (1934), 47 U. S. C. $\S \S 151,301-329$ (1946). But possible restraints on program content can arise as a result of the FCC's power to license stations on the basis of "public interest, convenience or necessity." The Supreme Court has confirmed the power of the FCC to concern itself with content in connection with licensing but based its decision on the shortage of broadcasting frequencies. National Broadcasting Company v. United States, 319 U. S. 190 (1943).

The FCC has made program content a criterion in granting and renewing licenses and in selecting among several prospective licensees. This action has been sustained by the courts. Johnston Broadcasting Co. v. FCC, 175 F. 2d 351 (D. C. Cir. 1949) ; Simmons v. FCC, 169 F. 2d 670 (D. C. Cir. 1948). Concern with the public service aspects of broadcasting has led the FCC to restrict editorializing on the air. The general policy has been laid down that licensees can editorialize but must provide an opportunity for listeners to hear different opposing opinions. See In the Matter of Editorializing by Broadcast Licensees, 1 Pike \& Fisher RR 91:201 (1949). In turn there arises the problem of access 
treatment accorded movies is pointed up by recent decisions barring local censorship of movies broadcast over television. ${ }^{\mathbf{1 0}}$

A major obstacle to granting movies First Amendment protection has been the 37-year-old Supreme Court decision in Mutual Film Corporation v. Industrial Commission, ${ }^{11}$ which held motion pictures outside the free speech clauses of a state constitution. ${ }^{12}$ Although this decision has been cited frequentily in numerous state and federal courts ${ }^{13}$ it need be no bar to bringing

to broadcasting facilities. In a case interpreting this decision the FCC held that a licensee did not have to provide time for the preaching of atheism. It was said that licensee must consider the extent of the interest of the people in his broadcast area on a particular subject to be broadcast. In re petition of Robert Harold Scott, FCC \#96050 (1949). Access to the air by political candidates is provided for in the Communications Act, 48 Stat. 1088 (1934), 47 U. S. C. $\$ 315$ (1946) which requires broadcasters to give equal opportunity to other candidates if they permit any candidate to speak. This section also prohibits censorship by the radio station over the content of a political address by a candidate. But this prohibition does not extend to persons speaking on behalf of candidates. Felix v. Westinghouse Radio Stations, 186 F. 2d 1 (3d Cir. 1950). On the subject of radio censorship see McClellan, Censorship of Radio Broadcasting (1938); Moser \& Lavine, Radio and the Law, 109-122 (1947); Stepamann, Radio, Television and Soctetx 201-251 (1950).

10. A regulation of the Pennsylvania State Censor Board requiring all films shown over television to be submitted for censorship was declared invalid in Allen B. Dumont Laboratories v. Carroll, 184 F. 2d 153 (3d Cir. 1950), cert. denied, 340 U. S. 929 (1951). The Court said that Congress had occupied the entire field of communication by radio and television by the Communications Act of 1934 .

11. 236 U. S. 230 (1915).

12. The Mutual decision approved an Ohio statute which provided that all films shown in Ohio were to be approved in advance by a state censor board. A companion case upheld a similar state censorship statute of Kansas. Mutual Film Corporation v. Hodges, 236 U. S. 248 (1915).

13. The most recent reliance on Mutual was in connection with the banning of The Miracle in New York State. The banning was sustained by the Appellate Division on the rationale of the Mutual decision. The court did not regard the free speech issue as open to question in the case: "Motion pictures have been judicially declared to be entertainment spectacles, and not part of the press or organs of public opinion." New York Herald Tribune, May 10, 1951, p. 1, col. 6.

The Miracle episode points up the many facets of the problem of movie censorship. Originally granted a seal of approval by the state Motion Picture Division, the film was labeled "officially and personally blasphemous" by the New York City Commissioner of Licenses who warned that the theatre's license would be revoked upon further showing of the film. New York Times, Dec. 24, 1950, p. 1, col. 2. This action was enjoined by the Supreme Court on the ground that the right to determine whether a picture is indecent, immoral or sacrilegious is vested solely in the State Education Department. New York Times, Jan. 6, p. 1, col. 2. Two days after this ruling Cardinal Spellman called upon all Catholics to stay away from the picture and all theatres showing it. New York Times, Jan. 8, 1951, p. 1, col. 2. After announcing that it had received hundreds of protests against the movie, the Board of Regents viewed the film, agreed unanimously that it was sacrilegious and revoked the license that had been granted by the Motion Picture Division. New York Times, Feb. 17, 1951, p. 1, col. 1. Text of Regent's Report, p. 9 , col. 2. 
movies within the protection of the First Amendment. The Mutual case preceded by ten years the holding in Gitlow v. New York ${ }^{14}$ that the First Amendment is a restraint on state action. ${ }^{15}$ Consequently, Mutual represents no direct holding that movies are not included with the federal Bill of Rights. ${ }^{16}$

The three-fold basis for the Mutual holding is invalid both by analogy to the legal position of other communication media and in the light of modern communication research. The court used an unsound constitutional criterion when it excluded movies from the free speech area on the basis that they are primarily a business. Operation for private profit has never controlled the constitutional status of other media of expression. ${ }^{17}$ A second basis, the

The most recent Federal case to cite the Mutual case as controlling is RD-DR Corporation and Film Classics Inc. v. Smith, 183 F. 2d 562 (5th Cir. 1950). See note 9 supra. Other cases are cited in note 6 supra.

14. 268 U. S. 652 (1925).

15. See Grosjean v. American Press Co., 297 U. S. 233 (1936), and Near v. Minnesota, 283 U. S. 697 (1931). Since the Gitlowe decision the Supreme Court has included a variety of means of communication within constitutional protection against state action. The First Amendment has been extended to picketing, Thornhill v. Alabama, 310 U. S. 88 (1940); distribution of leaflets in the street, Schneider v. State, 308 U. S. 147 (1939); house to house canvassing for sale of publications, Martin v. City of Struthers, $319 \mathrm{U}$. S. 141 (1943); distribution of crime magazines, Winters v. New York, 333 U. S. 507 (1948); playing of phonograph records, Cantwell v. Connecticut, 310 U. S. 296 (1940); and use of sound amplifiers, Kovacs v. Cooper, 336 U. S. 77 (1949).

16. At least one Justice has suggested that movies are to be given the same protections as other media. "We have no doubt that moving pictures, like newspapers and radio, are included in the press whose freedom is guaranteed by the First Amendment." Justice Douglas, in United States v. Paramount Pictures, Inc., 334 U. S. 131, 166 (1948). Justice Douglas voted to grant certiorari in the Lost Boundaries case; RD-DR Corp. and Film Classics, Inc. v. Smith, 183 F. 2d 562 (5th Cir.), cert. denied, 340 U. S. 853 (1950).

The role of motion pictures as an integral element in the formation of public opinion has been recognized also by the executive and legislative branches of the government, on state, national and international levels. The new constitution of Missouri protects freedom of speech, "no matter by what means communicated." Mo. Const. Art. I, Sect. 8. The Defense Production Act of 1950, Pub. L. No. 774, 82d Cong., 1st Sess. c. 932, $\$ 2402$ (e) (iii) (1950) exempts from regulation, as did its predecessor of World War II, 56 STat. 36 (1942), 50 U. S. C. $\$ 942$ (1942), the prices or rentals of any "press association, feature service, books, magazines, notion pictures, periodicals or newspapers." (Italics added.) The Act of Chapultepec recommended to the American nations the abandonment of measures of censorship of the press, radio and motion pictures. Resolution XXVIII, First Act of the Inter-American Conference on Problems of War and Peace, Pan American Union 69 (1945). The Administrator of the Economic Cooperation Act has defined the term "informational media" to include motion pictures, 14 FED. REG. 3916 (1949). Recognizing the force of films as instruments of idea communication, President Truman has asked the movie industry to join in a campaign of truth against Communist propaganda. N. Y. Times, Sept. 9, 1950, p. 11, col. 8.

17. The traditional basis for operation of mass media in the United States has been private profit. Although some critics have feared that the profit motive and monopolization of the mass media have been detrimental to their functions as organs of public information, the courts have never seen fit to take these factors into account on the 
movies' capacity for evil, seems equally unsound. Such a capacity has certainly affected the type and amount of community control, but has never meant that all expression within a medium will be restricted at the outset. It has meant only that when a particular act of expression is sought to be restrained, the community's need for protection against the evil must be weighed against the value of the expression. ${ }^{18}$

A third basis for the Mutual decision reflected traditional judicial suspicion of the arts in general, expressed in terms of a dichotomy between entertainment and ideas. Mutual, regarding the movies as "spectacles", placed the entire medium within the entertainment category. Similar judicial treatment has been accorded the legitimate stage, long subject to arbitrary restraint. ${ }^{10}$

question of constitutional status. See ERNST, The First FreEdom (1946); Sieprrann, Radio, Television and Soctety 218-251 (1950); Nixon, Implications of the Decreasing Number of Competitive Nezuspapers in CoMrMunications IN MODERN SOCIETY 43 (Schramm ed. 1948). In the handbill distribution cases the Supreme Court specifically rejected the sale of publications as a criterion for determining whether the publications were to be protected by the First Amendment. Although a distinction was drawn between religious tracts and commercial handbills, this distinction was based on consideration of content rather than on the fact of sale. See Schneider v. State, 308 U. S. 147, 165 (1939).

18. A recent statement of the balancing process in free speech cases is that of Judge Learned Hand in United States v. Dennis, 183 F. 2d 201, 215 (1950) : ". . . 'clear and present danger' depends upon whether the mischief of the repression is greater than the gravity of the evil, discounted by its improbability." See also Justice Frankfurter concurring in Niemetko v. Maryland, 340 U. S. 268 (1951); American Communications Association v. Douds, 339 U. S. 382 (1950). For discussions of the value judgments involved see Riesman, Civil Liberties in a Period of Transition, 3 Public Policy YEARBook 33 (1942) and sources cited note 1 supra.

19. The long tradition of state control of theatrical performances started in England at least as early as 1543 when the Master of Revels was empowered to supervise the religious mystery plays. Tudor censorship, however, dealt impartially with the theater and the other institutions able to disseminate ideas. Under the Commonwealth theatres were suppressed entirely and in 1737 Parliament passed an Act recognizing the stage as a medium apart from literature, the press and platform. This Act gave the Lord Chamberlain the power to license all theatres and review all plays in advance of presentation. The Theatres Act of 1843 reaffirmed the Chamberlain's right to censor stage plays when "it is fitting for the preservation of good manners, decorum or of the public peace." For the history of stage censorship in England see e.g., Knowles, The Censor The Drama and the Filar (1934), Palarer, The Censor and the Theatres (1913).

Legal control of dramatic performances has had a similar history in the United States. For many years plays were forbidden altogether in Massachusetts. The drama has not been considered as a medium within the protection of the First Amendment. The police power of the states and the delegation of power to municipalities have been held to authorize censorship of plays. See People v. Wendling, 258 N. Y. 451, 180 N. E. 169 (1932), Opinion of the Justices, 247 Mass. 589, 143 N. E. 808 (1924). Stage plays are subject to licensing laws and obscenity statutes. The obscenity statutes provide a basis for criminal prosecution for presenting an objectionable play. These criminal prosecutions have furnished the occasion for closer judicial definition of obscenity in the case of the theatre than in that of the movies. See, e.g., Chicago v. Kirkland, 79 F. $2 \mathrm{~d} 963$ (7th Cir. 1935) ; Commonwealth v. McGann, 213 Mass. 213, 100 N. E. 332 (1913). In some cities power is given licensing authorities to suspend a theatre's license if they consider a play 
Several factors are responsible for this judicial separation of entertainment from the organs of public opinion: the Puritan tradition which long characterized the stage as evil $;^{20}$ and a longstanding feeling that fictional expression does not convey ideas significant to the formation of public opinion. ${ }^{21}$

Analysis of modern communication research casts doubt on the validity of this dichotomy between entertainment and ideas. Evidence indicates that specific ideas of importance can be conveyed within a fictional context and

immoral or indecent. The threat of license revocation or criminal prosecution is sufficiently strong that play producers and theatre owners will frequently amend or withdraw plays in accord with suggestions made before exhibition by prosecuting or licensing officials.

On the subject of stage censorship generally, see CHAfEe, FreE Speech iN tHE UntTed States 529-36 (1941), Grant \& Angoff, Massachusetts and Censorship, 10 B. U. L. REv. 36, 147 (1930). Many of the considerations and arguments which make movies an important medium of public opinion formation are applicable also to the legitimate theatre. For discussion of the role of the theatre in opinion formation see Doob, Public Opinion and Propaganda 527-9 (1948).

20. For the Puritan origins of the tendency to regard the theatre as a distinctly special type of communication see note 19, supra. This same attitude was carried over to this country and found its first expression in the banning of all stage plays in Massachusetts. See $2 \mathrm{DE}$ Tocoueville, Democracy IN AMrerica 75-6 (Reeve ed. 1889). In addition to the Puritan dislike for public entertainments was the feeling that people ought to occupy their free time with civic affairs and other serious matters. See Reisman and Denney, Do the Mass Media "Escape" From Politics? in REAdER IN Public Opinion and Communication 327 (Berelson and Janowitz eds. 1950) and sources cited note 19 supra.

21. In addition there is an attitude that the need for relaxation and the quest for knowledge are incompatible. This view has been held by some motion picture artists who emphasize the entertainment aspect of their medium. The post war developments in motion picture content, however, do not support this view. Several films attacking social abuses were high on the money-making lists, indicating widespread popular interest. Kracauer, Those Movies with a Message, 196 HARPER's 567 (1948). The different results reached by courts in obscenity prosecutions involving newspapers and novels may indicate an unsympathetic treatment of fictional expressions. Both are protected by the First Amendment. However, the application of obscenity laws has resulted in much more restraint on novels than on newspapers. See note 31 infra. One case has drawn a distinction between the serializing of a novel in a newspaper and the book, itself. Commonwealth v. Herald Pub. Co., 128 Ky. 424, 108 S. W. 892 (1908).

Some doubt has been cast on the need for showing importance of theme to gain constitutional protection. In Winters v, New York, 333 U. S. 507 (1948), the Supreme Court held unconstitutional a New York statute prohibiting distribution of magazines containing principally "criminal news or stories of deeds of bloodshed or lust." The court held such publications entitled to First Amendment protection despite the fact that it could "see nothing of value to society in these magazines." Justice Reed may have sounded the death knell of the idea-entertainment dichotomy in this case when he denied the contention that "protection for a free press applies only to the exposition of ideas." $\mathrm{He}$ concluded that the "line between the informing and the entertaining is too elusive" for the protections of the First Amendment. 
that fictional expression is frequently responsible for creating a general framework for the development of public attitudes and behavior. ${ }^{22}$

Even accepting the dichotomy, the suggestion that movies provide entertainment, not ideas, and consequently fall outside First Amendment protection, is not supported by a consideration of the effect of motion pictures on public opinion. At the time of the Mutual decision, the infant movie industry was designed primarily to provide amusement. ${ }^{23}$ However, motion picture producers have given increasing attention to the idea content of their

22. Studies which emphasize the role of the arts in conveying symbolic expression significant in the formation of public attitudes include FEAring, Towards a Psychologicas Theory of Human Communication, (Unpublished manuscript supplied by Bureau of Applied Social Research, Columbia University 1950) ; MEAd, Mind, Self and Soctety, 268 (1934), Morris, Signs, Syarbols and Behavior 193-195 (1946), Sinte, Lasswell \& Casey, Propaganda, Communication and Public Opinion (1946).

For a succinct description of modern communication theory see LASSwEL, THE Structure and Function of Communication in Society in Mass Communications 102 (Schramm ed. 1949).

One of the important ways in which fictional expression affects political and social attitudes is by strengthening preferences for certain values in terms of which political issues may later be decided. The effectiveness of artistic expression is not measured alone by the immediate conversion of opinion but also by reinforcement of ideological position and the bringing into consciousness people's latent attitudes. The fictional media, particularly the movies, can have an important infuence on preparing people to think about pubTic issues. They are effective in bringing issues to people's attention in a situation where interest has been aroused. See Berelson, Communications and Public Opition in ConrMUNICATIONS IN Modern Society, 167-185 (Schramm ed. 1948), Fearing, Influence of the Movies on Attitudes and Behavior, 254 Annars 70-79 (1947), Inglis, An Objective Approach to the Relationship Between Fiction and Society 3 Als. Soc. REv. 526 (1938), Slesinger, The Film and Public Opintion in PRINT, RAdio, and FILM IN a Dexrocracy 79 (Waples ed. 1942).

In the case of the movies where a unique combination of audio-visual elements is used it is probably psychologically impossible to make a coherent film involving human actions, reactions, and interactions without at the same time presenting some ideological position toward that activity. The creations of Walt Disney and Charlie Chaplin illustrate movies dealing in an indirect way with community problems and values. Disney's folk fables reduce the complexities of urban living to natural simplicities while Chaplin reduces a bewildering society to comprehensible satire. See Grey, Communication and the Arts in The Communication of Ideas 119-142 (Bryson ed. 1948) and Fearing, supra, at 72.

Even within the movie medium a distinction between educational and fictional expression is inaccurate. There is no clear cut line between the documentary type of film and the theatrical film in terms of emotional appeal since facts can be as emotional in their effect as fiction. See Fiske \& Handel, Motion Picture Research: Response Analysis, Journal of Marketing, Jan., 1947, p. 273.

23. In 1915 the modern feature picture was unknown, movie theatres were of the nickelodeon type and movies were directed primarily at foreign born populations in big cities. Pictures were frequently made in a day at a cost of about $\$ 500$. From an artistic standpoint they were crude since the finer techniques of film making had not yet been developed. For the history of motion picture development see e.g. Mayer, Socrorogy of Filar (1946); Rosten, Hollywood (1941); Thorp, America at the Movies (1939). 
medium. ${ }^{24}$ Although only a small percentage of total film production is concerned directly with political and social issues, the percentage is rising steadily. ${ }^{25}$ Moreover, consideration of themes alone in determining the effect of

24. That movie producers are becoming more aware of the potentialities of their medium as a factor in opinion formation is shown both by statements of industry leaders and the increasing number of films dealing with political and social issues. In a communication to the Yale LAw Journal, December 7, 1950, Darryl F. Zanuck, production head of Twentieth Century-Fox, stated: "Certain pictures are made simply to entertain. Many others are intended to project a problem, a social idea or to stimulate thought. Motion pictures have for years taken the stand that it is within their province to present a viewpoint on controversial issues." Jesse L. Lasky has said that the movie industry is obligated to inform the public as well as entertain. N. Y. Times, Nov. 1, 1950, p. 43, col. 6 . See also Wyler, Statement of Principles, N. Y. Times, June 18, 1950, sec. II, p. 5, col. 5.

On the issue of whether films should deal with controversial public issues it has been said that the film is not a good vehicle for political debate since each film must take sides and fifteen months would be required to prepare a film rebuttal. Statement of James K. McGinnis in Should Hollywood Make Movies to Infunence Public Opinion?, Bunletin of America's Town MeEting of the ATR 11 (September 6, 1945). It has been suggested that this difficulty could be overcome by use of short subjects, incorporating contradictory opinions with arguments presented pictorialiy. INGLLS, FREEDOM oF THE Movies 16 (1947).

A short cartoon was the center of recent debate in the Middle West when Freshlaid Plans was attacked as a "one-sided political editorial in pictures." The picture, a barnyard fable said to satirize government planning, was said to be an attack upon the Brannan Plan. The debate pointed up the belief of the protestors in the effectiveness of screen editorializing. See New York Times March 18, 1951, p. 1, col. 2; March 19, 1951 , p. 22 , col. 1; March 25, 1951, sect. VI, p. 28, col. 2.

25. An early survey of motion picture content showed that from 1920 to 1930 there was an increase in the number of films devoted to such topics as biography, documentary, social problems, history, and war. Dale, The Content of Motion Pictures (1935). This trend has continued to the present. A critical magazine recently listed a number of postwar films which "came to grips with those grimmer themes which are . . the true stuffs of our times." Saturday Review of Literature, Aug. 26, 1950, p. 26. In its regular survey of contemporary films the Consumer's RESEARCE BULLETIN lists a large number of films under categories of potential political and economic importance. Consumer's Research BulletiN, No. 950, p. 16. For recent surveys of motion picture content which are not limited to categorizing movies by central theme but examine content from a psychological, anthropological, or philosophical viewpoint see Doob, Public Opinion and Propaganda 511-514 (1948); Powdermaker, Hollywood, The Drearar Factory (1950) passim; Wolfenstein \& Lettes, Movies: A Psychologrcal Study (1950) passim; Riesman \& Denney, in Reader IN Pudlic Opinion And Comanunication 327-333 (Berelson and Janowitz ed. 1950); Jones, Quantitative Analysis of Motion Picture Content, 6 PuB. OR. Q. 411 (1942).

While the proportionate amount of attention given to material of political importance has been increasing in the case of motion pictures, it has been decreasing in some of the protected media. Surveys of trends in newspaper content show that progressively less space is being given to items of political and social importance. The categories of sports, comic strips and society reports are on the increase. See Mott, Trends in Nezuspaper Content in Mass Comarunications 337 (Schramm ed. 1949) and Taecuber, Changes in the Content and Presentation of Reading Material in Minnesota Weekly Newspapers, 1860-1929, 9 Journalism Q. 281 (1932). An analysis of major themes in certain leading magazines indicates that a very small percentage of attention is given 
films does not reflect adequately their influence. A film labeled "musical comedy," for example, may through its combination of character, plot, and setting have a significant impact on audience attitudes, aspirations, and behavior. ${ }^{26}$

The significance of the motion picture as an organ of public opinion is due not only to the nature of movie content but also to the technological features of the medium. The addition of speech to the screen since the date of the Mutual decision has contributed to the effectiveness of movies as a communicator of ideas. ${ }^{27}$ Dramatization through a unique combination of sight and sound makes the ideas presented by movies comprehensible to more of the audience than is the case in any other medium except television. ${ }^{28}$ Moreover,

to "social issue" themes. Johns-Heine \& Gerth, Valnes in Mass Periodical Fiction 1921-1940 in Mass Comarunications 379 (Schramm ed. 1949).

26. Customary content surveys do not adequately reflect the full impact of motion picture content on public opinion. In addition to the main feature, movie patrons see newsreels, documentaries, travel films and other short subjects. The main features, themselves, are not always in one content category alone. A film which is primarily concerned with a love story may contain elements of history, travel, biography, etc. Most of the limited content analysis to date has been centered on character and plot types. It has been suggested that a more complete picture would be gained by consideration of settings, types and duration of photographic shots, and relative degrees of physical and psychological realism in films. Fiske \& Handel, Motion Picture Research: Content and Audicnce Analysis, Journal of Marketing, Oct., 1946, pp. 129-134. The difficulties involved in using themes as the basis for determining effect are discussed in Berelson \& Lazarsfeld, The Analysis of Communication Content, (Preliminary Draft 1948). A sophisticated approach to the problem of communication effect requires consideration of the reciprocal relation between screen and spectator. Rather than regarding films as cause or effect it is necessary to recognize that the influence of movies is determined by the many individual and social relationships which motivate thought and action. See Cressey, The Motion Picture Experience as Modified by Social Background and Personality, 3 Axr. Soc. REv. 516 (1938).

27. Since the first talking picture was produced in 1926, eleven years after the Mutual decision, this fact alone argues for bringing the movies under the free speech amendment.

The advent of sound made possible the development of the movies into the mass medium it is today. The screen became attractive for English-speaking Americans and as the level of education rose a greater audience became available. Movies were no longer produced primarily for the consumption of foreign language groups. By 1947 57,500,000 admissions were sold during an average week. Confroential Motron Picture AtTendance Report, No. 3, (Audience Research, Inc. 1947). In a public opinion sampling to test relationships between audiences for the various communication media, $61 \%$ of those sampled had seen a movie within the month. LAZARSFELD \& KENDALL, Radio Listening in America 1-17 (1948).

The average American family spends more money on movies than on any other communication medium. Table in Mass Conrmunications 548 (Schramm ed. 1949). For a discussion of the other technological devices developed since 1915 to make the movies a more effective medium see Davy, Footnotes to the Filn (1937) ; Lindgren, The Art of the Filar 19-31, 97-116 (1948) ; Schary, Case History of a Movie (1950).

28. The range of comprehension for movies is much higher than that for most of the other mass media. In tests to determine audience comprehension, 8 year olds averaged $60 \%$ as compared to adult standards, 12 year olds $80 \%$ and 16 year olds $90 \%$. See Dale, 
movies assure a high degree of attention and retention. ${ }^{29}$ The focusing of an intense light on a screen, the dramatizing of fact and opinion, the semidarkness of the room where distracting ideas and suggestions are eliminated all contribute to the effectiveness of movies in shaping and changing attitudes. ${ }^{30}$

\section{Communication by Picture in COMMUNICATIONS IN MODERN SOCIETX 72 (Schramm ed. 1948).}

29. Although experts differ on the degree of retention gained by the motion picture it has been established that retention for this medium does not follow the usual curves of forgetting. A study of retention of film material dealing with soil conservation showed no loss of information after a lapse of six weeks to three months. Dale, Communication by Picture in CoMmunications IN MODERN Soctety (Schramm ed. 1948). Another test compared retention of material contained in novels with material in movies adapted from the same books. Much more of the content of the movie was remembered longer. Jones, Children at the Movies, 27 J. of THE AMr. Assoc. of UNIv. WONEN 221-226 (1934). Experiments conducted by the War Department reported in KIAPPER, EFFECTS of MASs MEDIA, IV-8-IV-20 (1950), showed that although factual material presented in movies might be forgotten, attitude changes were actually magnified with the passage of time. See also Doob, Propaganda: Its Psychology and ITS TECHNIQUE 375-377 (1935).

30. The potential of the motion picture in formation of opinion has been demonstrated by scientific tests measuring the effects of specific films on the attitudes of audiences. By measuring the opinion of the audience on a certain issue before and after seeing the film it has been possible to assess the extent of opinion change on the issue treated by the movie. These tests have also shown that the effect of motion pictures is cumulative. Thus, even though one movie related to a social issue may not significantly affect the attitude of an individual or group, continual exposure to films of a similar character will produce a change. For report on the results of these tests see Charters, Motion Pictures and Youth in Reader in Public Opinion and Communications 397 (Berelson \& Janowitz ed. 1950).

Experiments conducted to determine the effectiveness of armed service orientation films showed marked effects on knowledge of factual material presented in the movies as well as considerable effect on opinion. These tests also studied the various factors influencing the effects of films such as intellectual ability, motivation and previous indoctrination. See Hovzand, Experingents on Mass Communication (1949). One test established a motion picture as an important factor in a political campaign. See Perentesis, Effectiveness of Motion Picture Trailer as Election Propaganda, 12 Public OpInron Q. 465 (1948). Other tests which support the view that movies can affect public opinion are reported in Rosenthal, Change of Socio-Economic Attitudes Under Radical Motion Picture Propaganda, Archrves of Psychology No. 166 (1934); Wiese \& Cole, A Study of Children's Attitudes and the Infuence of a Commercial Motion Picture, 21 J. of Psycr. 151-171 (1946). One test minimized the effectiveness of Sister Kemny in changing community attitude. See Hulett, Estimating the Net Effect of a Commercial Motion Picture Upon the Trend of Local Public Opinion, 14 AMr. Socto. Rev. 263 (1949). On effects of films generally see BluMrer, Movies AND Conduct (1933); Dale, op. cit. supra note 29; Holoday \& Stoddard, Getting Ideas From the Movies (1933); Kiapper, EFfects of MAss Mrdia (1950).

The effectiveness of the film as a method of instruction and influence is indicated by the wide use of movies in such fields as education, religion, industry, armed forces and government propaganda. For results of tests on the effectiveness of orientation films used by the armed services during the war see Hovland, Expernasents on Mass Com- 
If the law recognizes that the entertainment-idea dichotomy is invalid and grants movies constitutional protection, pre-censorship by state administrative boards would continue to be possible, but would probably be limited to protection against obscenity in its common law context. ${ }^{31}$ Statutes requiring

sunications (1949). Totalitarian countries have long recognized the power of films in their propaganda programs. See Doob, Public Opinion and Propaganda 501-504 (1949). The State Department utilizes films in its informational and propaganda activities abroad.

Pantiandle Eastern Pipeline Company recently showed Congressional leaders a movie criticizing the Federal Power Commission's rate-making policies in an effort to get favorable Congressional action on natural gas rates. New York Times, March 14, 1951, p. 51, col. 3. These non-commercial films are not subject to censorship unless shown to the public in commercial theatres.

Newreels and documentaries shown in theatres are subject to censorship unless exempted by statute. Pathe Exch. v. Cobb, 202 App. Div. 450, 195 N. Y. Supp. 661 (3rd Dep't 1922), aff'd 236 N. Y. 539, 142 N. E. 274 (1923). New York, Kansas and Pennsylvania have exempted newsreels from the censorship statutes.

31. The Supreme Court has implied in several cases that prior restraint on expression for purposes of protecting against obscenity would not violate the First Amendment. The language used would indicate that licensing on the basis of obscenity would be sustained. See e.g., Near v. Minnesota, 283 U.S. 697, 716 (1931); Chaplinsky v. New Hampshire, 315 U.S. 568, 571-572 (1942); Lovell v. Griffin, 303 U.S. 444, 451 (1937). Prior restraint for other purposes, such as control of noise (Kovacs v. Cooper, 336 U.S. 77 (1949)) and use of sirens for parades (Cox v. New Hampshire, 312 U.S. 569 (1941)) has been sustained. Dictum in Terminiello v. Chicago, 337 U.S. 1, 4 (1949) also lends support to the view that censorship would be permissible under certain circumstances.

Obscenity statutes would continue to provide the basis for criminal prosecution. The exact way in which obscenity codes will be applied to the movies is difficult to determine since their application has varied with each medium of communication.

In most states books and newspapers are subject to the same obscenity statutes, but with very different results. With respect to books there has been vigorous prosecution at times and a rather broad definition of obscenity. The traditional standard is "whether the tendency of the matter charged as obscenity is to deprave and corrupt those whose minds are open to such immoral influences, and into whose hands a publication of this sort may fall." Regina v. Hicklin, L.R. 3 Q.B. 360. This standard has been discarded in recent Federal decisions and added to in New York. The new Federal standard, laid down in United States v. One Book entitled "Ulysses", 72 F. 2d 705, 707 (2d Cir. 1936) is whether the book "taken as a whole has a libidinous effect." This test has been followed in Hannegan v. Esquire, 327 U.S. 146 (1946) and Parmelee v. United States, 113 F.2d 729 (D.C. Cir. 1940). In New York such considerations as literary merit, historical description, moral teaching and representation of an individual or class have been added to the test. Opinions of experts and critics are also considered in New York. See People v. Brainard, 192 App. Div. 816, 183 N. Y. Supp. 452 (1st Dep't 1920). The uncertain state of obscenity law in New York, is indicated by the fining of the publishers of Memoirs of Hecate County without an opinion in the trial court. This action was sustained without opinion by the New York Court of Appeals, Doubleday \& Co. v. New York, 297 N.Y. 687, 77 N.E. $2 d 6$ (1947), and affirmed by an equally divided court in the United States Supreme Court. Doubleday \& Company v. New York, 335 U.S. 848 (1948). This case is noted in 47 CoL. L. Rev. 686 (1947).

None of the book tests has been applied to newspapers. In the few cases where prosecutions have been made courts have not defined obscenity. See Commonwealth v. Herald Publishing Company, $128 \mathrm{Ky} .428,108$ S.W. 892 (1908); State v. MicKee, 73 
approval of each film before exhibition would have to be revised to afford to the censor specific criteria, such as "obscene, lewd, lascivious, filthy, indecent or disgusting." Vaguer standards, such as tending "to corrupt morals or incite to crime," would probably fall unless strictly construed by state

Conn. 18, 46 Atl. 409 (1900); State v. Van Wye, 136 Mo. 227, 37 S.W. 938 (1896); O'Brien v. State, 37 Ohio St. 113 (1881). An example of the varying applications of obscenity is illustrated by the case of the film, Birth of $a$ Baby. The film was banned by the New York State censors. Subsequently, Life magazine published still shots from the film and was acquitted in an obscenity prosecution. People v. Larsen, 5.N.Y.S.2d 55 (Ct. Spec. Sess. 1938). On the subject of obscenity prosecutions generally, see Chafee, Government and Mass Communications Vol. I, 200-234 (1947); Grant \& Angoff, Massachusetts and Censorship, 10 B.U.L. Rev. 37, 147 (1930); Notes, 34 Cornell L.Q. 442 (1949); 53 Harv. L. Rev. 403 (1940). Many cities and states now cut individual scenes from films as obscene. Courts have interpreted obscenity statutes to require consideration of a challenged book in its entirety. See, e.g., Parmelee v. United States, 113 F.2d 729 (D.C. Cir. 1940); United States v. One Book entitled "Ulysses", 72 F.2d 705 (2d Cir. 1936). Under such an interpretation isolated scenes or lines of dialogue would not condemn the entire movie. However, the fact that a scene can be more easily cut from a film than can a page from a book may bring different decisions with respect to the movies.

Courts have looked to the expected audience in determining obscenity. But the fact that a part of the possible audience may be peculiarly susceptible to obscene influence has not meant that the entire public is to be denied the opportunity of reading the book or seeing the play. Federal courts look to effect upon all who might have access to the publication, not to a particular class of readers. See Hannegan v. Esquire, 327 U. S. 146 (1946); United States v. Levine, 83 F. 2d 156 (2d Cir. 1936). But see Commonwealth v. Buckley, 200 Mass. 346, 86 N. E. 910 (1909).

In the case of the movies, statistics show that thirty per cent of the audience is under eighteen years of age. Confidential Motron Picture Attendance Report, No. 3 , (Audience Research, Inc. 1947). This will influence court decisions on how far states and cities may go in their application of morality statutes. An additional protection may be provided by licensing regulations restricting children's attendance at movie theatres. Connecticut forbids children under fourteen to attend theatres after six p.m. unless accompanied by an adult. CoNn. GEN. STAT. $\$ 8677$ (1949). Detroit has a similar ordinance. DET. CoMrp. ORD. c. 320, p. 866 (1945). In Chicago there is provision in the censorship ordinance for the issuing of permits limiting exhibition to persons over 21 . ChICAGo Code $\$ 1954$ (1911). Such a plan would avoid the necessity for making all films conform to a standard acceptable for a teenage audience. The plan might be worked out so that children would be admitted only at certain times during which hours only films approved by a licensing board or review committee could be shown.

Exhibitors may still be influenced by unofficial pressure of prosecuting authorities to withdraw films from exhibition. Such pressure has resulted in the suppression of books, despite the fact that they are a constitutionally protected medium. By suggesting that the sale of a certain book will be considered a violation of an obscenity statute, public officials, supported and frequently spurred on by local watchdog societies, can force a local bookseller to remove a book from sale. See ChafeE, Free SpeEch IN THE United States, 529-532, 536-540 (1941); Cairns, Freedom of Expression in Literature, 200 Annals 76 (1938); Jenkins, Legal Basis of Literary Censorship, 31 VA. L. REv. 83 (1944). A possible way of avoiding this problem by means of a declaratory judgment statute has been tried in Massachusetts. Under this statute the bookdealer can get a jury trial on the issue of obscenity in a declaratory judgment action. Mass. ANN. Laws c. 272, §28c (Supp. 1950). See Note, 59 Harv. L. Rev. 813 (1946). 
courts to mean the encouragement of an actual breach of the law. ${ }^{32}$ Banning on grounds of sacrilege would probably be invalid. ${ }^{33}$ And misuse of standards of decency to outlaw movies on political and social problems would be struck down by subsequent judicial review.

The same inducement to compliance-the fear of a criminal prosecution-is present in the case of the local theatre owner. Book retailers and movie exhibitors differ significantly in that the resources of the movie producer or distributor may be more readily available to a local theatre manager than are the resources of a publishing house to a single bookseller. This willingness of producers and distributors to challenge suppression of films is shown by the three recent cases discussed in note 9 supra. Producers and distributors were parties to two of the actions and the Motion Picture Association has leant its support by filing briefs.

32. The censorship system under the First Amendment would differ from the present one by substitution of stricter standards to guide administrative determination. See note 31 supra. In cases involving licensing of expression the court has insisted on careful statutory wording. See, e.g., Kunz v. New York, 340 U.S. 290 (1951) (ordinance giving administrative official discretionary power to control in advance the right to speak in streets on religious matters invalid despite fact that ordinance applied only to one who ridicules and denounces other religions); Hague v. C.I.O., 307 U.S. 496 (1939) (ordinance requiring permit for public assembly in streets or parks held a violation of First Amendment because of lack of standards to guide administrative discretion). In Winters v. New York, 333 U.S. 507 (1948), the Supreme Court refused to permit conviction under an obscenity statute for publication of stories inciting to crime. A state statute requiring a license for a parade was sustained against an objection of vagueness because the administrative discretion was limited to "consideration of time, place and manner." Cox v. New Hampshire, 312 U.S. 569,575 (1941).

In criminal prosecutions under obscenity statutes there has been an attempt to develop an objective test. See note 31 supra. Personal predilection and prejudices will be less controlling in a court determination of obscenity than under present censorship procedure. This attempt at objectivity is indicated most clearly by Judge Pound in People v. Wendling, 258 N.Y. 451, 453, 180 N.E. 169 (1932), in finding a play not violative of the obscenity code: "The question is not whether the scene is laid in a low dive where respectable people are not found or whether the language is that of the barroom rather than the parlor. The question is whether the tendency of the play is to create lustful and lecherous desires."

33. An ordinance prohibiting expression of views which "ridicule or denounce any form of religious belief ... or preach or expound atheism or agnosticism" was held a violation of the First Amendment because it gave an administrative official too much discretion to control religious expression in advance of utterance. Kunz v. New York, 340 U.S. 290 (1951). A statute requiring an application for a certificate to solicit funds which gave an administrative official the power to determine whether the cause was a religion was deemed a violation of the Fourteenth Amendment as a censorship of religion. Cantwell v. Connecticut, 310 U.S. 296 (1940). In The Miracle case, note 13 supra, the court rejected the distributor's contention that the standard of "sacrilege" in the censorship statute was unconstitutional for vagueness and as a violation of the separation of church and state. The court said that full inquiry into religious ideas was protected by the First Amendment but ". . . motion pictures, staged for entertainment alone are not within the category of inquiry and discussion." This language implies that a different decision might be reached were the movies recognized as a First Amendment medium. N.Y. Herald Tribune, May 10, 1951, p. 14, col. 4. 
Control not involving prior restraint would also be limited by constitutional tests. If a statute controlling political expression were applied to a movie, the clear and present danger test would probably limit permissible restraint. ${ }^{34}$ The distributor or exhibitor could challenge the statute's application and get a judicial viewing of the film to determine whether its exhibition would constitute a sufficient threat to the community to warrant its banning. ${ }^{35}$ At this point the factors which make movies a unique medium of communication would be considered in balancing the value of the expression against the need for community protection..$^{36}$ The powerful effect of movies on the minds of the audience would be an important factor in determining the extent of permissible control.

Vaguely-drawn breach of peace ordinances today make possible the permanent banning of films on the basis of discretionary judgments as to the effect of the film on public order. ${ }^{37}$ With respect to media protected by the First Amendment, however, courts have applied the clear and present danger standard to test such restraints. They have further insisted that breach of

34. In the recent case of United States v. Dennis, 19 U.S.L. WeEK 1185, 3323 (U.S. June 5, 1951), the Supreme Court applied the clear and present danger test to determine the constitutionality of a statute restraining political expression. Prior to this case some doubt had been cast on the applicability of the clear and present danger standard in cases where a statute defined a particular type of political expression as a danger to the community. Presumption of validity was accorded the statute in Gitlow v. New York, 268 U.S. 652 (1925). In a recent case the Court seemed to emphasize the degree of interference with speech rather than the clear and present danger test in upholding the non-Communist affidavit provisions of the Taft-Hartley Act. American Communications Ass'n v. Douds, 339 U.S. 382 (1950). However, in some earlier cases the test was applied to determine the validity of statutes governing political expression and their application in particular instances. Whitney v. California, 274 U.S. 357 (1927); Fiske v. Kansas, 274 U.S. 380 (1927).

35. Movies would be subject to whatever restraints on political expression were upheld for other protected media. With movie content as closely circumscribed as it is today the problem of running afoul of an anti-subversion statute seems remote. However a statute forbidding expression designed to overthrow the government would be applicable to the movies.

36. For discussion of the factors to consider in the balancing process see cases cited in note 18 supra.

37. In the case involving the banning of Lost Boundaries, supra note 9, the basis for forbidding the picture was that it would "adversely affect the peace, morals and good order" by showing inter-racial relations in a way that might provoke disturbance. Compare this language with that in Terminiello v. Chicago, 337 U.S. 1 (1949) where a Chicago ordinance was declared invalid as an interference with free speech because it permitted conviction on the vague standard that the speech "stirred people to anger, invited public dispute or brought about a condition of unrest." The common law concept of breach of the peace was declared too general and undefined to sustain a restraint on speech in Cantwell v. Connecticut, 310 U.S. 296 (1940). As long as movies are not protected, however, neither the ordinance nor the action can be reviewed except for abuse of administrative discretion. There is no weighing of the possible danger to the community's peace against the community's interest in the film expression. 
peace ordinances clearly define the punishable offense. ${ }^{3 s}$ Thus, although exhibition of movies could be halted consistently with the First Amendment, this action would be carefully scrutinized by the courts.

Even with movies under the First Amendment, the theater building itself would still be subject to licensing laws for such purposes as zoning, fire laws, and sanitary codes. Of course administrative officials may use these laws as a cloak for controlling film content; but the only remedy for that is for the public and the courts to keep close tab on the officials to prevent them from abusing their powers.

Freeing motion pictures from arbitrary official censorship will not necessarily leave them unhampered as a medium of expression. Many non-legal factors influence movie production and exhibition. These factors may minimize the need for judicial protection of community morality. But at the same time, they may inhibit the freedom of the movies to discuss controversial issues.

Organized interest groups, possessing potential power of boycott, can cause a producer to abandon certain stories or make changes in screen plays. ${ }^{30}$ Religious, social, professional, racial, national, and business groups actively

38. Arrest of a street speaker under a breach of the peace law was sustained this term by the Supreme Court. Feiner v. New York, 340 U.S. 315 (1951). The action was sustained because the police were motivated solely by a proper concern for the preservation of order, there being no evidence that the action was aimed at the speaker's views and opinions. A breach of the peace statute was upheld in Chaplinsky v. New Hampshire, 315 U.S. 568 (1942). The Court approved that restraint on speech on the ground that the statute was narrowly limited and defined to cover specific conduct within the province of a state to control.

39. Actual boycott is the ultimate sanction at the disposal of interest groups, and the threat of this economic weapon makes such groups influential at all stages of movie production. Boycott can take the form of suggestions to membership that they not attend a certain picture, picketing before a theatre showing an objectionable film, and public appeals to avoid the picture. Still more persuasive is the threat that members will boycott any picture shown at the offending theatre or any film produced by an offending studio. Another threat which Hollywood feels from these groups is their political power to get restrictive legislation passed.

For examples of boycotts see the threat by Cardinal Dougherty in Philadelphia to boycott the theatre showing Forever Amber as well as any other theatre presenting films made by the same studio, Powdernaker, Holly wood: The Dreadr Factory 69 (1950); recent picketing in New York over the showing of The Miracle, Crowther, Strange Case of the Miracle, Atlantic, April, 1951, pp. 35-39; negro protests against Song of the South, Noble, The Negro IN FilMs 218-219 (1948); and agitation against the showing of Oliver Twist by the Anti-Defamation League of B'nai B'rith, 159 PuBlisher's WeEKLY 254 (1951). The Sons of Liberty also protested against Oliver Twist by boycotting all productions of the British producer and then extending the boycott to pictures made by other British firms. Seldes, The Great Audience 100 (1950).

The theatre showing The Iron Curtain in 1948 was picketed by left wing groups and counter picketed by Catholic War Veterans. The theatre also received a threat that it would be bombed if it did not withdraw the controversial film. See New York Times May 14, 1948, p. 28, col. 6. A bombing threat was made during the Miracle controversy. See Crowther supra. 
apply such pressures. ${ }^{40}$ Producers use information gained from these sources in determining profit potentialities of pictures. Industry organizations work

40. Many organizations maintain committees which preview films for one or more of the following reasons: (1) to inform their membership generally about recent films; (2) to supervise moral content; (3) to further specific aims of the organization. National reviewing committees are maintained by the following organizations: The American Library Association, American Legion Auxiliary, General Federation of Women's Clubs, National Council of Jewish Women, National Federation of Music Clubs, National Legion of Decency, National Society, Daughters of the American Revolution, and $\mathrm{Na}$ tional Protestant Motion Picture Council. In addition, state or regional committees are maintained by such groups as the American Association of University Women, California Congress of Parents and Teachers, California Federation of Business and Professional Womens Clubs and Southern California Council of Church Women. Other organizations which preview films are the Associated Women of the American Farm Bureau Federation and Girl Scouts of the United States. Opinions of the previewers are publicized through the publications of the organizations and movie trade publications such as the Joint Estimate of Current Motion Pictures published weekly by the Motion Picture Association of America. The National Legion of Decency puts out a weekly "moral estimate" of current motion pictures. Films are listed in four general categories: Morally Unobjectionable for General Patronage; Morally Unobjectionable for Adults; Morally Objectionable in part for all; Condemned. In the issue of December 7, 1950, 70 films were listed as unobjectionable for all, 75 for adults only; 115 were objectionable in part and 71 were condemned.

An industry-supported agency which previews pictures is the National Board of Review. The Board, whose activities are financed by fees charged producers for review of their films, classifies pictures, disseminates information about them, and organizes audience support for films it considers worthy. The agency has also worked closely with organizations seeking to improve motion picture content but opposing legal censorship. For description of the history and functioning of the National Board of Review see INGLIS, FreEDOM of THE MovIES 74-82 (1947).

Operations of the General Federation of Women's Clubs were described in communication to Yale LAw Journal from Mrs. Joseph R. Chesser, Adviser, Division of Motion Pictures, dated December 7, 1950, in Yale Law Library. The organization maintains a preview committee in New York which sees all films before they are released for public exhibition. During the period June, 1947-Feb. 1950647 films were previewed. 42\% were found suitable for young people; $23.2 \%$ were classified for adult consumption only and $34.8 \%$ were recommended for children. Only about $1 \%$ were not recommended for public exhibition. This group has protested vigorously against use of source material based on the life of notorious criminals. The clubwomen protested against the production of a film based on the life of Al Capone.

Two groups making concerted efforts with respect to treatment of negroes in films are the National Association for the Advancement of Colored People and the International Film and Radio Guild. These groups led a campaign against the filming of Uncle Tom's Cabin in 1946 and were successful in having the producer abandon the project. NobLe, Negro IN FILMS 218 (1948).

Reactions of other nations to the way in which their nationals and history are presented are quite influential because a substantial portion of film rentals comes from abroad. Kracauer, National Types as Portrayed by Hollywood, Pub. Or. Q., Fall, 1947, p. 346 .

A scene in one film was reshot at the request of the State Department which objected to showing a group of Mexican school children without shoes. To assist in the Good 
with committees of these groups to reduce objectionable features in films previewed by the committees and to get the views of these groups on future productions. ${ }^{41}$

A second factor limiting movie expression and controlling moral content is the system of self-regulation embodied in the Motion Picture Production Code. ${ }^{42}$ About $95 \%$ of all pictures released in the United States receive

Neighbor program the producers took the scene with shoes on. Powdermaker, HollyWOOD: DREAMY FACTORY 120 (1950).

Some control over movie content is exercised by the armed forces. As a result of the help which producers obtain from the Army and Navy there has developed a practice of cooperation between the armed forces and the motion picture industry. In return for assistance in production the armed forces received the right to censor films produced with their aid. See Litzky, Censorship of Motion Pictures in the United States (Thesis submitted for Degree of Doctor of Philosophy in the School of Education of New York University 1947).

For a detailed study of all films in which judges, lawyers, courtrooms and the law were involved, see Factual Study of Judges, Lazoyers in Motion Pictures, 33 A.B.A.J. 650 (1947). The survey concluded, after analysis of 104 pictures in which lawyers appeared, that the legal profession was being treated fairly. Sixty-five pictures were sympathetic, 21 indifferent and 18 unsympathetic. Before filming Mad With Much Heart which concerns a policeman who turns sadist under the pressure of his job the producers sought and obtained the approval of police departments in Los Angeles and Boston. New York Times, April 23, 1950, sect. II, p. 5, col. 1.

Recent activity by pressure groups includes the attack on Born Yesterday in some Catholic papers as a "marxist satire". New York Times, Dec. 1, 1950, p. 31, col. 1, and the cancellation of the showing of Bicycle Thief in Queens because of protests from local Knights of Columbus that the movie "glorifies a thief". New York Times, Feb. 16, 1951, p. 27, col. 7 .

The American Humane Association enforces a general rule against the killing or wounding of an animal on the screen. Hence adjustments were necessary in the filming of The Brave Bulls. Cutting techniques and special camera angles had to be used to convey the three climaxes in the bullfight. New York Times, April 16, 1950, sec. II, p. 6, col. 5.

41. For a description of the close working arrangements between producers and interest groups see Seldes, The Great Audience, 89-104 (1950).

It seems doubtful that any serious production of art which probes at all deeply into the vast range of human experience can avoid treading on the sensibilities of some racial, religious, economic, political or other interest group. If approval of all the groups involved must always be had the results will tend to be unreal and insipid. On the subject of movie pressure groups generally see Brown, Wishful Banning, Saturday Review of Literature, March 12, 1949, p. 24; Holmes, Sensitivity as Censor, Saturday Review of Literature, Feb. 26, 1949, p. 9; and sources cited note 40 supra.

42. The code starts with the explicit assumption that motion pictures shown in theaters are "primarily to be regarded as entertainment." In its section headings are summarized the subjects concerning which treatment is controlled: crimes against the law, sex, vulgarity, obscenity, profanity, costume, dances, religion, locations, national feelings and repellant subjects. The code is given in full in Internatronal Motron Picture Almianac 646-56 (1949-50 ed.).

There are indications however that the Production Code Authority does not limit itself to subjects laid down specifically in the code. According to SELDEs, supra, note 41, at 67 the producers of Best Years of our Lives were forced to fight hard to include a 
the approval of the Production Code Authority before release. ${ }^{43}$ Member producers are required to submit all scripts and finished pictures for approval.

banker portrayed as callous to the needs of returned veterans. Fall of Valor was recently abandoned at the suggestion of the Johnston Office despite the fact that the novel about homosexuality was rewritten in terms of a breakdown of a good marriage. 159 Publisher's WeEkLy 254 (1950). Oliver Twist was first denied and then granted the seal of approval after considerable revision of the film. The Production Code Authority's stand on this picture has been attacked by the National Council on Freedom From Censorship, National Board of Review, and the New York chapter of the American Council for Judaism. New York Times, Nov. 29, 1950, p. 45, co1. 4; New York Times, February 22, 1951, p. 33, col. 3.

After the film The Lawless was submitted to the Code Authority, the producers added several roles portraying more decent, solid citizens in a community where race riots were occurring. The Authority disapproved plans for adapting Detective Story to the screen because it deals with abortion. Following this decision film director William Wyler declared that certain subjects are untouchable because of code administration. New York Times, July 23, 1950, sec. II, p. 5, col. 2. Because of the Code's restrictions on treatment of political corruption, changes had to be made in The Racket recently to temper the cynicism of the original movie. Scenes depicting luxurious living by gangsters were also eliminated. Since the Code does not recognize the third degree, the scene of the original version in which a police captain threatens to beat a gangster had to be cut. New York Times, March 11, 1951, sec. II, p. 5, col. 1.

The code itself operates as a restraint on motion picture expression. In addition, there are indications that producers may be using the code as an excuse for keeping production channeled along safe and tested lines. See INGLIs, Freedom of the MoviEs 183 (1947).

In addition to self-imposed censorship, pressure groups are responsible for some of the eliminations attributed to the code. Pressure forced deletion of the clerical background of Cardinal Richelieu from The Three Musketeers. The code provision appealed to was the section providing that ministers should not be portrayed as villains. Liff, Oct. 25, 1948, p. 58. A recent illustration of the restrictions of the code is the case of the projected film The Left Hand of God. The story concerns the impersonation of a priest by an American flyer captured by a Chinese warlord. The film was objected to because it showed the administration of the Sacraments by an imposter. Already certain parts of the story have been eliminated. At the same time there is appearing in New York a French film God Needs Men in which a fisherman takes over priestly functions when the regular priest leaves the village. The International Catholic Film Office gave this picture an award for having "contributed the most to the spiritual and moral uplift of humanity this year." The different reactions to the French and the American films demonstrates that the offense of sacrilege is very much a function of time, place and interpretation. Barry, Jean Delamoy and "God Needs Men", New York Times, April 8, 1951, p. 5, col. 5; Brady, Hollywood in China, New York Times, April 1, 1951, p. 3, col. 1; Crowther, But Is It Sacrilege, New York Times, April 1, 1951, p. 1, col. 8 .

43. The Code comes into operation even before the purchase of a book, play or story for a movie. Producers seek an opinion as to acceptability under the code of material they wish to purchase. The next stage is the submission of the shooting script. If this basic story outline is acceptable an opinion will be sent to the producer, indicating what parts must be eliminated to make all details conform to the Code. If the basic story is unacceptable, producers and Code officials confer to arrive at revisions which will bring the script within Code requirements. These close working arrangements continue throughout production. When the film is completed, the Authority reviews it again and if it 
Defenders of the Code point to it as the best alternative to legal censorship and contend that producers are free to bring any social problem to the screen provided it is presented in a morally acceptable manner. ${ }^{44}$ Critics claim that the Code is limited in its effectiveness and that it makes realistic portrayal of some problems difficult if not impossible. ${ }^{45}$ Some modification of the Code may be required if the removal of legal censorship is to promote honest treatment of contemporary problems and avoid a succession of stereotyped films. ${ }^{40}$

A third non-legal restraint on motion picture expression is the organization of the industry and the nature of its audience. The major theatre circuits, closely allied with the large producing studios, have had a powerful voice in determining the type of films produced. ${ }^{47}$ Exhibitors generally are more

is satisfied issues a certificate of approval. See Doob, Public Oprnion and Propacanda, 507-510 (1948); Shurlock, The Motion Picture Production Code, 254 AnNars of tre AMrERICAN ACADEMY 140 (1947).

44. See Shurlock, supra note 43, at 145; Schary, Censorship and Stcreotypcs, Saturday Review of Literature, April 30,1949, p. 9. For a defense of the code as selfprotection for movie makers see Hodgins, $A$ Ronndtable on the Movies, Life, June 27, 1949 , p. 90.

45. In certain respects the code defeats its own purposes. By close attention to detail the technical appearance of virtue is maintained, while movies are full of sex, crime and violence. On the effectiveness of the code see Serdes, THE GREAT AuDIENCE 64-8S (1950); Powderaraker, Hollywood: The Dream Factory 73-78, S0-81 (1950). See note 42 supra.

46. The code as now formulated and administered reflects the existing requirements of the many state and local censor boards. Abolition of censorship should bring some relaxation in the code. However, the primary reason for its existence is a public relations function. Formulated at a time when the public standing of the movie industry was low, the code has been developed on the thesis that the way to keep the public favorably disposed toward the industry is to eliminate material objectionable to important segments of public opinion. For the history of the formation and development of the Code see INGLIS, FREEDOM OF THE Movies 116 (1947). This pressure may continue to be influential even if movies are accorded First Amendment protection. Since the application of obscenity statutes and clear and present danger test might be influenced by popular attitudes toward the movies, the industry may want to continue its present policy of minimizing offense whenever possible.

47. The motion picture industry is divided into three mutually dependent parts: production, distribution, and exhibition. The great bulk of American movies are produced by eight major companies. These same companies control the major centers of distribution. Prior to recent anti-trust actions the five largest producers also owned theatres. In determining the type of pictures to be produced the large theatre circuits affiliated with the major producing studios have been most influential. The five major producing studios have in the past made substantial portions of their profits from theatre operation as against production. Income statistics for 1939 showed that film rentals accounted for an average of only $36.4 \%$ of the volume of business. HUErTIG, Economic Control of the Motion Picture Industry 70, Table VI (1944). The effect of the anti-trust action is shown by figures of net income for Paramount. In the first quarter of 1949 when Paramount owned its large theatre chain it netted $\$ 5,675,000$. In the first quarter of 1950 after it had lost its theatres the figure was $\$ 1,441,000$. Business Weel:, June 24,1950, p. 26 . When confronted with the choice of producing films or staying in the theatre management business all producers decided to continue to make pictures. 
interested in assuring steady attendance by the same people than in attracting new customers. Hence there is pressure by exhibitors for formula movies designed for instant acceptance by the regular audiences. ${ }^{48}$ As a result of this pressure, producers may try to aim their films at a mass audience representing many diverse cultural groups. Moreover, the high cost of making a feature film, ${ }^{49}$ added to the influence of financing. banks, ${ }^{50}$ encourages concentration on production of pictures assured of immediate appeal. However, there are indications that this fear of arousing controversy may be diminishing. With revenues declining, ${ }^{51}$ some critics are calling for films that will satisfy

Reasons for this decision are falling theatre revenues and the advent of television which may cut more deeply into the theatre business, than into the demand for movie production. Divorcement of producers from their theatres may reduce the power of the distribution and former theatre management departments of the major studios. But the influence on production of the circuits created by this divorcement is difficult to determine. The divorcement of producers from their theatres may make it more difficult for studios to undertake experimentation. Darryl F. Zanuck, production head of Twentieth Century Fox, has said it would have been difficult to produce Wilson had it not been for the possibility of exploiting the film in the studio's own theatres. Hollywood's Magic Mountain, Fortune, Feb., 1945, p. 208. For discussion of the economic structure of the movie industry see Huetrig, op. cit. supra, at 54-95, 113-142; Inglis, Freedom of the Movies 36-54 (1947); Motron Picture Industry-A Pattern of Control, TNEC Monogrape No. 43, 76th Cong., 2d Sess. (1941).

48. It has been estimated that 13-15 million individuals see the average Hollywood class "A" production. Since the size of the audience is thus limited, repetitive attendance is of great concern to theatre owners. A public opinion survey shows that $52 \%$ of the public goes to movies more than once a month. CANTRI, Public OpINIoN, 1935-1946 (1951). To develop movie going as a habit it has been thought necessary to concentrate on themes with tested box office success. Another factor making for sameness of product is the fact that exhibitors are greatly influenced by attendance on the first day of a picture's run in a metropolitan theatre. It is important to get a large audience on the first day in order to ensure subsequent bookings. To guarantee this type of response it is necessary to have films to which the regular audience will go almost automatically. See Seldes, The Great Audience 13, 38-39 (1950).

49. If a movie costs less than $\$ 1,000,000$ it is tagged as a Class B film. The major features cost about $\$ 3,000,000$. The most expensive film of all time is now in production. Quo Vadis will cost about $\$ 10,000,000$. See Schulberg, Movies in America: After 50 Years, Atlantic, Nov., 1947, p. 115; Hollywood's Magic Mountain, Fortune, Feb., 1945, p. 153.

50. Film production is financed largely through banks which demand regular fixed charges. Bank financing tends to restrict variety and experimentation. PowDERMIAKER, Hollywood: The Dream Factory 51-52 (1950).

51. Surveys of postwar trends in movie revenues have indicated a steady decline. The contribution to national income of motion pictures dropped from a high of $\$ 1,116,-$ 000,000 in 1946 to $\$ 871,000,000$ in 1949. Motion Picture Division, Office of Industry and Commerce, U.S. Dept. of Commerce. In September, 1950 Audience Research reported that the average person is buying 7\% fewer movie tickets than in 1940 . During the first six months of 1950 attendance was off $9 \%$ from that of 1949 . Monday Morning Post, Sept. 25, 1950. A survey of profits on 146 pictures during 1950 showed that only 12 brought back more in the domestic market than the amount spent on production and distribution. Brady, Hollywood Takes Stock, New York Times, March 12, 1950, sec. II, p. 5, col. 7 . 
more kinds of interest in order to attract a larger proportion of the population to the movie theatres. ${ }^{52}$ Such a movement would increase the number of films dealing with issues of significance to political and social discussion.

As a result of these various non-legal restraints, the limiting of legal censorship will not automatically result in the fullest development of the motion picture as a contributor to the formation of public opinion. Nevertheless, control of such censorship is a necessary first step. The temptation to use the present highly discretionary powers of administrative regulation will become greater as movies undertake discussion of controversial subjects. Therefore, First Amendment protection will become more important at the very time movies make their greatest contribution to the political process.

52. The suggestion has been made that the industry develop additional first-run circuits of medium-sized theatres. Producers could then make medium-budget films which would not have to possess record-breaking mass appeal in order to make money. See Walter Wanger quoted in Serdes, THE GREAT AudIence 39 (1950). A call for abandonment of the old aspiration of making movies with universal appeal in favor of films made for a particular audience is given in Variety, quoted in Crowther, Is There An Audience?, New York Times, Oct. 11, 1950, sec. II, p. 1, col. 8. See also Hodgins, A Ronndtable on the Movies, Life, June 27, 1949, p. 90.

Research in radio casts doubt on the idea that the only way for a mass medium to make money is to produce the same type of product continually. Demand for any commodity, particularly movies, is not fixed but is susceptible of influence from changes in the product itself. Since the supply of a mass medium tends itself to create demand, if more movies on serious themes were produced more people might develop a greater interest in them. Movies with serious themes have been successful at the box office in recent years. See note 21 supra. These theories on the importance of availability of the communication in determining the size of its audience are discussed in Lazarsfeld, Audience Research in Reader in Public OpInIon and CominuniCation 345-346 (Berelson \& Janowitz ed. 1950) ; Waples \& TyLer, What the People Want to Read About: A Study of Group Interests and a Survey of Problens in Adult Reading (1938). 